\title{
Short-term glutamine supplementation decreases lung inflammation and the receptor for advanced glycation end-products expression in direct acute lung injury in mice
}

Yin-Ching Chuang ${ }^{1,3}$, Huey-Mei Shaw ${ }^{2}$, Chi-Chung Chen ${ }^{3}$, He-Jia Pan ${ }^{2}$, Wei-Chih Lai ${ }^{2}$ and Hui-Ling Huang ${ }^{2 *}$

\begin{abstract}
Background: Glutamine (GLN) has been reported to improve clinical and experimental sepsis outcomes. However, the mechanisms underlying the actions of GLN remain unclear, and may depend upon the route of GLN administration and the model of acute lung injury (ALI) used. The aim of this study was to investigate whether short-term GLN supplementation had an ameliorative effect on the inflammation induced by direct acid and lipopolysaccharide (LPS) challenge in mice.
\end{abstract}

Methods: Female BALB/c mice were divided into two groups, a control group and a GLN group (4.17\% GLN supplementation). After a 10-day feeding period, ALI was induced by intratracheal administration of hydrochloric acid (pH 1.0; $2 \mathrm{~mL} / \mathrm{kg}$ of body weight [BW]) and LPS (5 mg/kg BW). Mice were sacrificed $3 \mathrm{~h}$ after ALI challenge. In this early phase of ALI, serum, lungs, and bronchoalveolar lavage fluid (BALF) from the mice were collected for further analysis.

Results: The results of this study showed that ALI-challenged mice had a significant increase in myeloperoxidase activity and expression of interleukin (IL)-1 $\beta, I L-6$, and tumor necrosis factor-a in the lung compared with unchallenged mice. Compared with the control group, GLN pretreatment in ALI-challenged mice reduced the levels of receptor for advanced glycation end-products (RAGE) and IL-1 3 production in BALF, with a corresponding decrease in their mRNA expression. The GLN group also had markedly lower in mRNA expression of cyclooxygenase-2 and NADPH oxidase-1.

Conclusions: These results suggest that the benefit of dietary GLN may be partly contributed to an inhibitory effect on RAGE expression and pro-inflammatory cytokines production at an early stage in direct acid and LPS-induced ALI in mice.

Keywords: Glutamine (GLN), Acute lung injury (ALI), Receptor for advanced glycation end-products (RAGE), Inflammation

\section{Background}

Acute respiratory distress syndrome (ARDS) is often seen in critically ill patients, and increases their risk of secondary bacterial pneumonia due to direct gastric fluid reflux, bacterial pneumonia, and systemic sepsis [1]. Inflammatory cytokines can recruit inflammatory cells from the blood and increase the permeability of the alveolar-capillary

\footnotetext{
* Correspondence: cherry85@mail.chna.edu.tw

${ }^{2}$ Department of Health and Nutrition, Chia-Nan University of Pharmacy and Science, Tainan, Taiwan

Full list of author information is available at the end of the article
}

membrane after an acute lung injury (ALI) challenge [2]. ALI is characterized by significant oxidative stress and inflammation in the lung, which can contribute to cellular injury $[3,4]$.

The receptor for advanced glycation end-products (RAGE) plays a critical role in the pathogenesis of direct acid or lipopolysaccharide (LPS)-induced ALI, and obstruction of RAGE signaling has a protective effect against ALI [5]. RAGE was markedly increased in bronchoalveolar lavage fluid (BALF) in a dose-dependent manner in direct acid ( $\mathrm{pH}$ 1.0)-induced ALI [6]. RAGE has been implicated as 
an early mediator of ALI, similar to other cytokines such as tumor necrosis factor (TNF)- $\alpha$ or interleukin (IL)- $1 \beta$ [6,7]. RAGE is considered a useful indicator of early stage ALI in alveolar epithelial type I cell injury, which correlated with the severity of lung damage [8]. RAGEligand interactions could result in the activation of nuclear factor (NF)- $\mathrm{kB}$ and caused subsequent serial immuneinflammatory processes [9].

Additionally, a previous report indicated that enhanced oxidative stress was often observed in endotoxin-induced ALI [3]. Selective inducible nitric oxide synthase (iNOS) inhibition by a NOS inhibitor was effective in reducing TNF- $\alpha$, IL- 6 , and nitrite/nitrate levels in BALF by acid aspiration in rats [10]. Antioxidant N-acetylcysteine (NAC) treatment protected the lungs from stress in the first $12 \mathrm{~h}$ after lipopolysaccharide (LPS) administered intratracheally (IT) and also decreased the mRNA expression of NF- $\mathrm{kB}$, IL-6, TNF- $\alpha$, and cyclooxygenase (COX)-2 inhibitors [11]. Thus, inhibition of oxidative stress is considered a potential strategy for ameliorating direct lung injury by LPS or acid challenge.

Glutamine (GLN) is a conditionally essential amino acid during critical illness and injury. GLN has been shown to improve clinical and experimental sepsis outcomes, owing to its anti-inflammatory and antioxidative properties $[12,13]$. Results of recent studies indicate that a single intravenous dose of GLN supplementation ameliorated lung and kidney injury and increased survival in a cecal ligation and puncture (CLP)-induced sepsis model by inhibition of the high-mobility group box protein-1 (HMGB-1)-mediated pathway, which was thought to be a late-stage mediator of systemic damage $[14,15]$. However, the mechanisms underlying the actions of GLN remain undefined, and may depend on the route of administration and the model of ALI used.

To date, no study had definitively described the effects of dietary GLN on IT administration of acid and LPS induced-ALI in mice. We hypothesized that GLN may have anti-inflammatory effects on a mouse model of direct acid and LPS-induced ALI. To test this idea, the mRNA and protein expression of proinflammatory cytokines and RAGE were measured. We aimed to determine whether short-term GLN supplementation has a protective effect in the early stages of injury.

\section{Methods}

\section{Animals and diets}

Six-week-old female BALB/c mice (body weight [BW], 17-20 g), purchased from the Laboratory Animal Center of BioLASCO (Taipei, Taiwan), were housed individually in stainless steel wire cages in a temperature- and humiditycontrolled room supplied with a regular 12-h light/dark cycle. All mice were allowed free access to a chow diet and tap water for 7 days before the study. The protocols for animal care and handling were approved by the Institutional Animal Care and Use Committee of the ChiaNan University of Pharmacy and Science (CN-IACUC101028).

Mice were randomly assigned to a control group $(n=31)$ and a GLN group $(\mathrm{n}=31)$. Table 1 shows the composition of the two test diets. Both diets were designed according to the AIN-93G formula, which was modified to contain 15\% soybean oil [16]. For the GLN diet, 4.17\% GLN was added to the formula, replacing casein and providing $25 \%$ of total amino acid nitrogen. The dose of GLN was based on previous studies indicating that this dosage of GLN had beneficial immunomodulatory effects $[17,18]$. Both diets were isonitrogenous and isocaloric. All mice were fed the test diets for 10 days. Finally, 10 mice from the control and GLN groups were sacrificed as unchallenged controls, and then the remainder was given the ALI challenge. After ALI challenge, nine mice in both groups were used for survival rate assessment. Twelve mice in both groups were killed with intraperitoneal injections of sodium pentobarbital $(50 \mathrm{mg} / \mathrm{kg}$ ) after $3 \mathrm{~h}$ of ALI challenge. For survival studies, an analgesic was not provided after ALI challenge. All of the mice were housed individually in a quiet, comfortable environment after ALI challenge. Then, the mice were observed once every $h$ for occurrence of mortality.

\section{Table 1 Composition of test diets ${ }^{a}$}

\begin{tabular}{|c|c|c|}
\hline & Control & GLN \\
\hline & \multicolumn{2}{|c|}{ (g/kg diet) } \\
\hline Corn starch & 449.5 & 457.8 \\
\hline Casein & 200 & 150 \\
\hline L-glutamine $(G L N)^{b}$ & - & 41.7 \\
\hline Sucrose & 100 & 100 \\
\hline Soybean oil ${ }^{\mathrm{a}}$ & 150 & 150 \\
\hline Alphacel non-nutritive bulk (fiber) & 50 & 50 \\
\hline AIN-93G mineral mixture & 35 & 35 \\
\hline AIN-93G vitamin mixture & 10 & 10 \\
\hline L-Cystine & 3 & 3 \\
\hline Choline bitartrate & 2.5 & 2.5 \\
\hline 2,5-di-tert-Butylhydroquinone & 0.014 & 0.014 \\
\hline \multicolumn{3}{|l|}{$\%$ Energy $^{c}$} \\
\hline Carbohydrate & 50.6 & 50.6 \\
\hline Protein & 18.4 & 18.4 \\
\hline Fat & 31 & 31 \\
\hline
\end{tabular}

${ }^{\mathrm{a}}$ Our test diets were $15 \%$ high fat diets that modified from the AIN-93G standard formula.

${ }^{\mathrm{b}}$ The dose of GLN supplement was provided $25 \%$ of total amino acid nitrogen. Both of diets were isonitrogenous.

'The two diets were isocaloric. 


\section{Acid and LPS-induced ALI model}

After 10 days of feeding, 21 mice in both groups were weighed and anesthetized with sodium pentobarbital (intraperitoneal [IP] injection) before inducing ALI by acid and LPS aspiration. The procedure for IT instillation was described in a previous report [19]. $\mathrm{HCl}(\mathrm{pH}$ 1.0, in sterile distilled water; $2 \mathrm{~mL} / \mathrm{kg} \mathrm{BW}$ ) was administered IT to each mouse. After $5 \mathrm{~min}$, LPS from Escherichia. coli (serotype 055:B5, Sigma Aldrich Co, LLC, St. Louis, MO, USA) was instilled IT (10 $\mu$ g in $50 \mu \mathrm{L}$ sterile saline; $5 \mathrm{mg} / \mathrm{kg} \mathrm{BW})[6,10]$. Twelve mice in both groups were sacrificed with IP injections of sodium pentobarbital $(50 \mathrm{mg} / \mathrm{kg}) 3 \mathrm{~h}$ after ALI challenge.

\section{Tissue sampling and preparation}

Blood was collected via the abdominal vena cava, and the lung tissue was excised and weighed. The blood was centrifuged at $3500 \times \mathrm{g}$ at $4^{\circ} \mathrm{C}$ for $10 \mathrm{~min}$ and the serum was stored at $-80^{\circ} \mathrm{C}$ for future total antioxidant system (TAS), TNF- $\alpha$, and IL- 6 analysis. A small piece of lung tissue (approximately $30 \mathrm{mg}$ ) was excised, placed in storage reagent (RNAfter, GeneMark Ltd, Tainan, Taiwan), and stored at $-80^{\circ} \mathrm{C}$ for RNA extraction and subsequent real-time polymerase chain reaction (PCR) analysis. The remaining sample was homogenized in an ice-cold potassium phosphate (KP) buffer (0.01 M; pH 7.4) containing $1.15 \% \mathrm{KCl}$, using a Potter-Elvehjem-type homogenizer with a Teflon pestle. A portion of the lung homogenate was centrifuged at $15,000 \times \mathrm{g}$ at $4^{\circ} \mathrm{C}$ for $30 \mathrm{~min}$, and the supernatant was taken as the post-mitochondrial fraction (PMS) for measuring the activity of antioxidative enzymes and for cytokine analysis. The pellets were resuspended in ice-cold KP buffer (50 mM phosphate buffer; $\mathrm{pH}$ 6.0) that contained $0.5 \%$ hexadecyltrimethylammonium bromide (HTAB), and were stored at $-80^{\circ} \mathrm{C}$ for further myeloperoxidase (MPO) analysis.

\section{Determination of MPO activity}

The method of MPO activity analysis was modified from that described in previous studies [20,21]. After snap freezing in liquid nitrogen and thawing for three cycles, samples were centrifuged at $14,000 \times \mathrm{g}$ at $4^{\circ} \mathrm{C}$ for $10 \mathrm{~min}$. Aliquots of the supernatants were incubated in a $50 \mathrm{mM} \mathrm{KP}$ buffer containing $0.05 \%$ hydrogen peroxide and $o$-dianisidine dihydrochloride $(0.167 \mathrm{mg} / \mathrm{mL})$. MPO activity was measured by the change in absorbance at $460 \mathrm{~nm}$ over $3 \mathrm{~min}$, using a spectrophotometric method. The protein content was determined using Lowry's method [22].

\section{Serum TAS, lung glutathione, and antioxidative enzyme analysis}

TAS was measured using commercially available enzymelinked immunosorbent assay (ELISA) kits, in accordance with the manufacturer's instructions (Cayman Chemical
Co, Ann Arbor, MI, USA). Analysis was finally read at $450 \mathrm{~nm}$ in a spectrophotometer. Glutathione (GSH) content and glutathione peroxidase (GPx), glutathione reductase (GR), glutathione S-transferase (GST), superoxide dismutase (SOD), and catalase activity were measured as described elsewhere [23,24].

\section{BALF collection}

Ten mice from both groups were used for BALF collection by bronchoalveolar lavage after ALI challenge. A 20 -gauge catheter was inserted into each mouse's trachea, and $1 \mathrm{~mL}$ sterile saline was flushed back and forth three times. The recovered lavage was then centrifuged at $15,000 \times \mathrm{g}$ at $4^{\circ} \mathrm{C}$ for $10 \mathrm{~min}$ [19]. The supernatant aliquots were stored at $-80^{\circ} \mathrm{C}$ for further analysis of cytokines and RAGE by ELISA.

\section{Quantification of cytokines and RAGE by ELISA}

Levels of IL-1 $\beta$, IL-6, TNF- $\alpha$, and RAGE were measured using commercially available ELISA kits, in accordance with the manufacturer's instructions (eBioscience, San Diego, CA USA and R\&D Systems, Minneapolis, MN, USA). Each result was finally read at $450 \mathrm{~nm}$ in a spectrophotometer.

\section{RNA isolation and mRNA detection}

Total RNA was extracted from the lung immersed in storage solution (RNAfter) using an illustra RNAspin Mini RNA Isolation Kit (GE Healthcare, Buckinghamshire, UK), according to the recommended protocol. The RNA quality was confirmed by a $28 \mathrm{~S}$ ribosomal RNA:18S ribosomal RNA ratio of 2 after ethidium bromide staining. Levels of mRNA for COX-2, iNOS, IL-1 $\beta$, IL-6, RAGE, and NADPH oxidase-1 (NOX-1), were determined by real-time PCR. Total RNA $(1 \mu \mathrm{g})$ was reverse-transcribed into first-strand cDNA using 200 units of Moloney murine leukemia virus (MMLV-RT; Promega Corp, Madison, WI, USA). PCR was performed using 50 ng cDNA, 2 SYBR Green PCR Master Mix (Applied Biosystems, Foster City, CA, USA), and 200 $\mathrm{nM}$ of the primer pair. The sequences of the PCR primers used are shown in Table 2. Amplification using 40 cycles of two steps $\left(95^{\circ} \mathrm{C}\right.$ for $15 \mathrm{~s}$ and $60^{\circ} \mathrm{C}$ for $\left.1 \mathrm{~min}\right)$ was performed on an ABI Prism 7300HT sequence detection system (Applied Biosystems, Foster City, CA, USA). To confirm the amplification of specific transcripts, melting curve profiles were produced at the end of each run. In this assay, glyceraldehyde-3-phosphate dehydrogenase (GAPDH) was used as an internal control. Each value was normalized to that of GAPDH, and then the relative mRNA abundance was calculated by taking the normalized value for the control group as 1 .

\section{Statistical analysis}

The main effects of dietary GLN and ALI were evaluated by two-way analysis of variance (ANOVA). The differences 


\begin{tabular}{|c|c|c|c|}
\hline Gene & $\begin{array}{l}\text { GenBank } \\
\text { accession }\end{array}$ & $\begin{array}{l}\text { Amplicon } \\
\text { size (bp) }\end{array}$ & Sequence \\
\hline \multirow{2}{*}{ cox-2 } & \multirow{2}{*}{ NM_011198 } & \multirow{2}{*}{147} & F: 5'-AAGCCGAGCACCTTTGGAG \\
\hline & & & R: 5'-ATTGATGGTGGCTGTITTGGTAG \\
\hline \multirow{2}{*}{ iNOS } & \multirow{2}{*}{ NM_010927 } & \multirow{2}{*}{63} & F: 5'-GGGCAGCCTGTGAGACCTT \\
\hline & & & R: 5'-TGAAGCGTTTCGGGATCTG \\
\hline \multirow{2}{*}{ IL-1 $\beta$} & \multirow{2}{*}{ NM_008361 } & \multirow{2}{*}{99} & F: 5'- GATCCCAAGCAATACCCAAA \\
\hline & & & R: 5'- GGGGAACTCTGCAGACTCAA \\
\hline \multirow{2}{*}{ IL-6 } & \multirow{2}{*}{ NM_031168 } & \multirow{2}{*}{140} & F: 5'- TCCAGTTGCCTTCTTGGGAC \\
\hline & & & R: 5'- GTGTAATTAAGCCTCCGACTTG \\
\hline \multirow{2}{*}{ Nox-1 } & \multirow{2}{*}{ NM_172203 } & \multirow{2}{*}{215} & F: 5'-CTGACAAGTACTATTACACGAGAG \\
\hline & & & R: 5'- CATATATGCCACCAGCTTATGGAAG \\
\hline \multirow{2}{*}{ RAGE } & \multirow{2}{*}{ NM_007425 } & \multirow{2}{*}{91} & F: ACTACCGAGTCCGAGTCTACC \\
\hline & & & R: CCCACCTTATTAGGGACACTGG \\
\hline \multirow{2}{*}{ GAPDH } & \multirow{2}{*}{ NM_008084 } & \multirow{2}{*}{123} & F: 5'-AGGTCGGTGTGAACGGATITG \\
\hline & & & R: 5'-TGTAGACCATGTAGTTGAGGTCA \\
\hline
\end{tabular}

F, Forward; R, Reverse; COX-2, cyclooxygenase-2; GAPDH, glyceraldehyde-3phosphate dehydrogenase; iNOS, inducible nitric oxide synthase; IL-1 $\beta$, interleukin $1 \beta$; IL-6, interleukin 6; Nox-1, NADPH oxidase; RAGE, advanced glycation end-products.

among the four groups were analyzed by Duncan's multiple range test. The significance of differences between two groups was analyzed by Student's $t$-test. The statistical significance level was set at $p<0.05$. All statistical analyses were performed using SAS software (SAS Institute Inc., Cary, NC, USA).

\section{Results}

Body weight gain, food intake, and lung weight

As shown in Table 3, ALI challenge reduced body weight gain and feeding efficiency. Food intake was not changed by GLN or ALI treatment. Lung weight and relative lung weight increased approximately $60 \%$ and $65 \%$ by ALI challenge, respectively. These results revealed that acid and LPS aspiration caused marked enlargement of the lung, but there was no effect of dietary GLN supplementation. GLN treatment had no adverse effect on growth in mice.

\section{Serum TAS, GSH, and antioxidative enzyme activity}

No significant differences in serum TAS, lung GSH, and superoxide dismutase (SOD) activity were observed among all groups (Table 4). The effects of lung catalase, GR, GST, and selenium-dependent glutathione peroxidase (Se-GPx) were significantly reduced in the ALI groups than in the unchallenged groups $(p<0.05)$. The GLN diet had a slight effect on ALI-challenged mice, but this did not reach statistical difference. These results revealed that GLN had no significant benefit on enhancement of antioxidative enzymes.

\section{Lung MPO acitivity and IL-1 $\beta$, IL-6, and TNF- $\alpha$ concentrations}

ALI-challenged mice had a significant increase in MPO activity and levels of IL-1 $\beta$, IL- 6 , and TNF- $\alpha$ of the lung compared with unchallenged mice (Table 5). The ameliorative effect of the GLN diet was noted for IL- $1 \beta$ and IL-6, and this phenomenon was dependent on ALI-challenge. GLN treatment reduced IL-1 $\beta$ and IL- 6 expression by $39 \%$ and $69 \%$, respectively, compared with the control group in ALI-challenged mice.

\section{Serum IL- 6 and TNF- $a$ concentrations and BALF RAGE, IL-1 $\beta$, IL- 6 , and TNF- $\alpha$ levels in ALI-challenged mice}

To examine the anti-inflammatory effect of GLN in ALI-challenged mice, we measured serum cytokine concentrations and used BALF for further analysis. Figure 1 shows that serum TNF- $\alpha$ concentrations did not differ between the control and GLN groups in ALI-challenged mice. In the GLN group, a marked reduction in IL-6 (37\%) was observed. As shown in Figure 2, BALF RAGE and IL-1 $\beta$ levels were significantly lower in the GLN group than in the control group of ALI-challenged mice. There were no significant differences in IL- 6 and TNF- $\alpha$ levels between the control and GLN groups.

\section{Lung mRNA expression in ALI-challenged mice}

To further examine the effect of dietary GLN on gene expression, we measured the mRNA levels of inflammatory cytokines, iNOS and COX-2, and the oxidant-generating enzyme, NOX-1. As shown in Figure 3, no statistical difference in iNOS expression was seen between the two groups. GLN treatment reduced COX-2 mRNA expression by $58 \%$ compared with the control group. The GLN group had significantly lower mRNA levels of IL-1 $\beta$ and IL-6 compared with the control group (39\% and 49\%, respectively). RAGE mRNA was significantly decreased in the GLN group. NOX-1mRNA was markedly lower in the GLN group than in the control group.

\section{Discussion}

In our previous studies, we used an animal model of severe ALI by both direct acid and LPS challenge for imitation of clinical cases of direct gastric fluid reflux and bacterial pneumonia. Our previous results indicated that RAGE, TNF- $\alpha$, and IL- 6 expression was significantly higher than that of the unchallenged mice at the early stage ( 3 and $6 \mathrm{~h}$ of injury), but all mice died $48 \mathrm{~h}$ after ALI challenge (data not shown). Using this severe ALI model, we speculated that GLN could reduce the expression of these cytokines at an early stage, consequently improving the outcome of ALI. Therefore, the aim of the present study was to determine whether short-term GLN supplementation had a protective effect in the early stages of injury. The dosage of GLN was approximately 
Table 3 Body weight gain, food intake, feed efficiency, and lung weight of mice ${ }^{a}$

\begin{tabular}{|c|c|c|c|c|c|c|c|}
\hline & \multicolumn{2}{|c|}{ Unchallenged } & \multicolumn{2}{|c|}{ ALI } & \multicolumn{3}{|c|}{$p$ values from Two-way ANOVA ${ }^{b}$} \\
\hline & Control & GLN & Control & GLN & ALI & GLN & $\mathrm{ALI} \times \mathrm{GLN}$ \\
\hline Initial body weight (g) & $20.0 \pm 0.9$ & $20.0 \pm 0.9$ & $20.1 \pm 0.8$ & $20.1 \pm 0.8$ & NS & NS. & NS. \\
\hline Body weight gain $(\mathrm{g} / \mathrm{d})$ & $0.25 \pm 0.09$ & $0.21 \pm 0.17$ & $0.19 \pm 0.10$ & $0.15 \pm 0.11$ & $<0.05$ & NS. & NS. \\
\hline Food intake $(\mathrm{g} / \mathrm{d})$ & $4.24 \pm 0.28$ & $4.11 \pm 0.30$ & $4.50 \pm 0.44$ & $4.32 \pm 0.84$ & NS. & NS. & NS. \\
\hline Feed efficiency $(\%)^{c}$ & $5.89 \pm 2.08$ & $4.90 \pm 4.36$ & $4.06 \pm 2.14$ & $3.40 \pm 2.49$ & $<0.05$ & NS. & NS. \\
\hline Lung weight (g) & $0.15 \pm 0.03$ & $0.14 \pm 0.01$ & $0.24 \pm 0.06$ & $0.23 \pm 0.04$ & $<0.001$ & NS. & NS. \\
\hline Relative lung weight (\%) ${ }^{d}$ & $0.65 \pm 0.10$ & $0.60 \pm 0.08$ & $1.09 \pm 0.27$ & $1.06 \pm 0.17$ & $<0.001$ & NS. & NS. \\
\hline
\end{tabular}

${ }^{a}$ Each value represents Mean \pm S.D., $\mathrm{n}=10-12$. NS., no significant difference.

${ }^{\mathrm{b}}$ The significance of differences among four groups were analyzed by two-way ANOVA. Values not sharing a same superscript letters in the horizontal row are significantly different from one another by Duncan's Multiple Range Test $(P<0.05)$.

${ }^{c}$ Feed efficiency $(\%)=$ body weight gain $(\mathrm{g}) /$ food intake $\left.(\mathrm{g})\right] \times 100$.

${ }^{\mathrm{d}}$ Relative lung weight $(\%)=$ (lung weight/body weight $) \times 100$.

$0.8 \mathrm{~g} / \mathrm{kg} \mathrm{BW}$ from the feed conversion, a dosage similar to that previously described [25]. As shown in Table 3, enteral GLN administration was safe and did not cause any adverse effects on growth. The survival rate $24 \mathrm{~h}$ after ALI challenge was 33\% in the GLN group and $11 \%$ in the control group (data not shown). The ameliorative effect of GLN supplementation on the survival rate was not complete, which may be a result of more severe injury in this model of ALI induced by two powerful chemicals. A study conducted by Zhou et al. [26] demonstrated that IP LPS injection plus $\mathrm{HCl}$ aspiration produced significant lung injury, compared with either LPS injection or $\mathrm{HCl}$ instillation alone. Therefore, dietary GLN supplementation had a beneficial effect only within 24 hours after this severe ALI challenge, but in the end could not rescue survival. We will try to modify this severe ALI model by reducing the dose of LPS/acid in next study to further explore the effect of dietary GLN on survival.

To elucidate the anti-inflammatory effect of GLN in ALI-challenged mice, we did not analyze BALF cytokines and lung mRNA expression in both unchallenged groups because we found that the levels of these cytokines of unchallenged controls were very low or undetectable in our previous study (data not shown). The other reason was to reduce this experimental cost and assay load, which caused this experimental design flaw in our studies. Therefore, the possible effects of GLN discussed below focus on the ALI-challenged condition in mice.

There are a number of possible explanations for the protective effect of GLN against ALI during sepsis, including enhanced expression of heat shock protein (HSP), activation of peroxisome proliferator-activated receptor (PPAR)- $\gamma$, buffering of oxidative stress, inhibition of HMGB-1 expression, and anti-inflammatory responses $[13,15]$. This model of acid and LPS introduced into the trachea led to a direct, chemically induced, tissue-level injury of the lung in such a short time that there was no immediate mounting of an immune response, as is observed in the normal model of septic system injury. Given our results, we speculated that the key function of GLN was to reduce the inflammatory response by inhibiting RAGE expression and pro-inflammatory cytokine production.

First, as shown in Figures 2A and 3E, this study demonstrated that dietary GLN could downregulate RAGE expression in the lung. RAGE is a marker of type I cell injury in ALI [8]. A previous report indicated that HMGB-1 was

Table 4 Serum TAS, lung GSH content, and anitixoidative enzyme activity ${ }^{a}$

\begin{tabular}{|c|c|c|c|c|c|c|c|}
\hline & \multicolumn{2}{|c|}{ Unchallenged } & \multicolumn{2}{|c|}{ ALI } & \multicolumn{3}{|c|}{$p$ values from Two-way ANOVA } \\
\hline & Control & GLN & Control & GLN & ALI & GLN & $\mathrm{ALI} \times \mathrm{GLN}$ \\
\hline Serum TAS (mM) & $1.13 \pm 0.11$ & $1.11 \pm 0.17$ & $1.04 \pm 0.07$ & $1.07 \pm 0.11$ & NS. & NS. & NS. \\
\hline GSH ( $\mu \mathrm{mol} / \mathrm{g}$ Lung) & $4.57 \pm 2.44$ & $4.62 \pm 2.72$ & $3.89 \pm 2.99$ & $6.42 \pm 2.52$ & NS. & NS. & NS. \\
\hline Catalase (unit/mg protein) & $29.1 \pm 2.4$ & $29.1 \pm 2.5$ & $21.3 \pm 2.1$ & $22.3 \pm 2.4$ & $<0.001$ & NS. & NS. \\
\hline GR (unit/g protein) & $30.6 \pm 3.6$ & $31.5 \pm 2.6$ & $27.3 \pm 3.3$ & $28.5 \pm 2.6$ & $<0.05$ & NS. & NS. \\
\hline GST (unit/mg protein) & $0.39 \pm 0.08$ & $0.41 \pm 0.08$ & $0.28 \pm 0.04$ & $0.30 \pm 0.04$ & $<0.001$ & NS. & NS. \\
\hline SOD (unit/mg protein) & $3.07 \pm 0.26$ & $3.32 \pm 0.24$ & $3.23 \pm 0.36$ & $3.28 \pm 0.47$ & NS. & NS. & NS. \\
\hline Se-GPx (unit/g protein) & $44.8 \pm 6.4$ & $45.4 \pm 9.1$ & $37.4 \pm 5.3$ & $43.6 \pm 5.4$ & 0.05 & NS. & NS. \\
\hline
\end{tabular}

${ }^{a}$ Each value represents Mean \pm S.D., $\mathrm{n}=10-12$. NS., no significant difference; GSH, glutathione; GR, glutathione reductase; GST, glutathione S-transferase; Se-GPx, se-dependent glutathione peroxidase; SOD, superoxide dismutase; TAS, total antioxidant system.

${ }^{b}$ The significance of differences among four groups were analyzed by two-way ANOVA. Values not sharing a same superscript letters in the horizontal row are significantly different from one another by Duncan's Multiple Range Test $(P<0.05)$. 
Table 5 Lung MPO acitivity and IL-1 $\beta$, IL-6, and TNF- $\alpha$ concentrations of mice ${ }^{\text {a }}$

\begin{tabular}{|c|c|c|c|c|c|c|c|}
\hline & \multicolumn{2}{|c|}{ Unchallenged } & \multicolumn{2}{|c|}{ ALI } & \multicolumn{3}{|c|}{$p$ values from Two-way ANOVA ${ }^{b}$} \\
\hline & Control & GLN & Control & GLN & ALI & GLN & $\mathrm{ALI} \times \mathrm{GLN}$ \\
\hline MPO acitivity (unit/g lung) & $7.97 \pm 13.5$ & $8.27 \pm 14.9$ & $207 \pm 92$ & $195 \pm 92$ & $<0.001$ & NS. & NS. \\
\hline IL-1 $\beta$ (ng/mg protein) & $0.02 \pm 0.01^{c}$ & $0.03 \pm 0.02^{c}$ & $0.18 \pm 0.1^{a}$ & $0.11 \pm 0.05^{b}$ & $<0.001$ & NS. & $<0.05$ \\
\hline IL-6 (ng/mg protein) & $0.11 \pm 0.04^{c}$ & $0.12 \pm 0.05^{c}$ & $1.69 \pm 1.26^{\mathrm{a}}$ & $0.56 \pm 0.34^{b}$ & $<0.001$ & $<0.05$ & $<0.05$ \\
\hline TNF-a (ng/mg protein) & $0.05 \pm 0.02$ & $0.06 \pm 0.03$ & $0.26 \pm 0.16$ & $0.15 \pm 0.17$ & $<0.001$ & NS. & NS. \\
\hline
\end{tabular}

${ }^{\mathrm{a}}$ Each value represents Mean \pm S.D., $\mathrm{n}=10-12$. NS., no significant difference.

${ }^{\mathrm{b}}$ The significance of differences among four groups were analyzed by two-way ANOVA. Values not sharing a same superscript letters in the horizontal row are significantly different from one another by Duncan's Multiple Range Test $(p<0.05)$.

a late mediator of endotoxin-induced ALI and an early trigger of inflammation in animal models via RAGE activation [27]. Administration of recombinant RAGE could attenuate injury in LPS-induced ALI in mice [7]. Recently, BALF RAGE was considered a sensitive indicator for direct lung injury in acid or LPS-induced ALI in mice, particularly in acid-challenged mice [7]. Yamakawa and colleagues [28] indicated that LPS stimulation resulted in release of RAGE into the media in a dose-dependent manner from cultured rat alveolar epithelial cells, and verified the that proteolysis was primarily caused by matrix metalloproteinase (MMP)-3 and -13. Therefore, we also measured MMP3 mRNA in the lung. The GLN diet decreased relative MMP-3 mRNA expression by $30 \%$, but this did not reach statistical difference (data not shown). Confirmation of whether the mechanism by which GLN treatment causes a decrease in RAGE expression is mediated by proteolysis is beyond the scope of this study. According to previous reports, attenuation of RAGE activation led to a decrease in ALI severity. Thus, we suggest that dietary GLN exerted its protective role by decreasing RAGE expression in ALIchallenged mice.

Second, we found that lung IL-1 $\beta$ and IL-6 levels were significantly lower in the GLN group with corresponding decreases in their mRNA expression than was observed in the control group. We speculate that proinflammatory cytokines such as TNF- $\alpha$, IL- $1 \beta$, and IL- 6 were released in the early stage of ALI challenge; in other studies, IL-6 was considered a particularly useful marker for prediction of the severity of sepsis. Previous reports revealed that enteral GLN supplementation for 3 weeks decreased lung IL-6 levels and regulated the immune response during CLP-induced sepsis $[29,30]$. Thus, we propose that GLN supplementation had an anti-inflammatory effect against ALI challenge at an early stage.

Third, worsening oxidative stress was a possible cause of ALI damage. To determine whether the antioxidant properties of GLN are associated with ALI-induced oxidative stress, we measured GSH and antioxidative enzymes. The lung GSH concentration and mRNA level of $\gamma$ glutamyl-cysteine-synthetase (data not shown) were unchanged in the GLN group. Recent experimental data have demonstrated that HSP70 enhancement is the main factor responsible for the beneficial effects of GLN on ALI during sepsis, because GLN is required for HSP generation $[15,25,31]$. It is unclear whether short-term dietary GLN supplementation is sufficient to generate the level of HSP required for buffering the acid and LPS-induced damage. Therefore, Hsp70 expression warrants further investigation. Interestingly, we found that mice that received GLN supplementation showed a marked reduction in lung COX-2 and NOX-1 mRNA. A previous study showed that lung COX-2 expression and activity were increased in acid-induced injury, and the actual role of COX-2 varied at different stages of injury [32]. NOX-1 has been identified as the major oxidant-generating enzyme in neutrophils and macrophages [33]. A previous report demonstrated that NOX-1 was responsible for more than $90 \%$ of the lipid-derived free radicals and was implicated in lung damage in an IT LPS-induced lung injury model
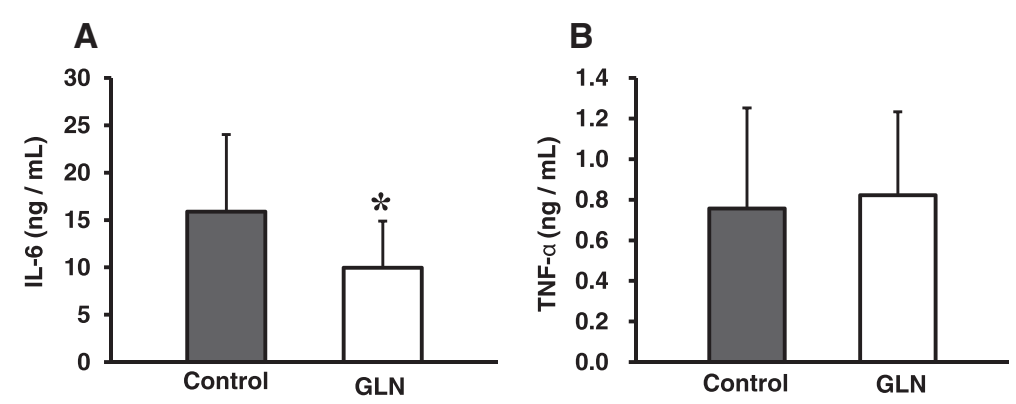

Figure 1 Serum IL-6 and TNF-a concentrations of ALI-challenged mice. (A) IL-6, (B) TNF-a. Data are presented as mean \pm standard deviation; $n=10-12$. The effect of GLN was evaluated by Student's t-test in two ALl-induced groups; ( ${ }^{*} p<0.05$ vs. the control group). 
A

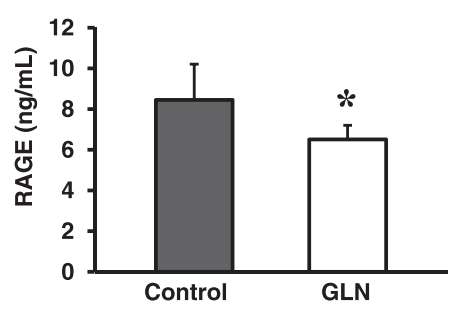

C

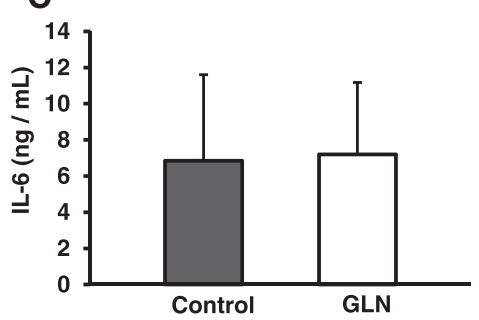

B

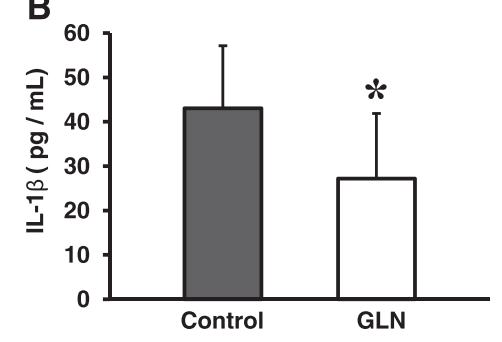

D

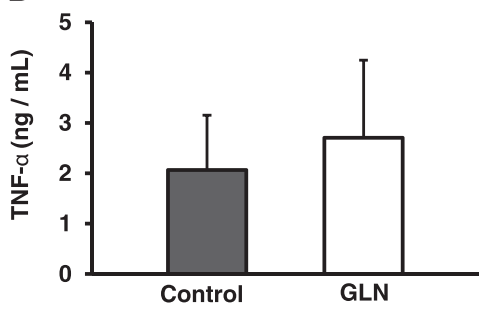

Figure 2 RAGE concentrations in the BALF of ALI-challenged mice. (A) RAGE; (B) IL-1ß; (C) IL-6; (D) TNF-a. Data are presented as mean \pm standard deviation; $n=10-12$. The effect of GLN was evaluated by Student's t-test in two ALl-induced groups ( ${ }^{*} p<0.05$ vs. the control group).
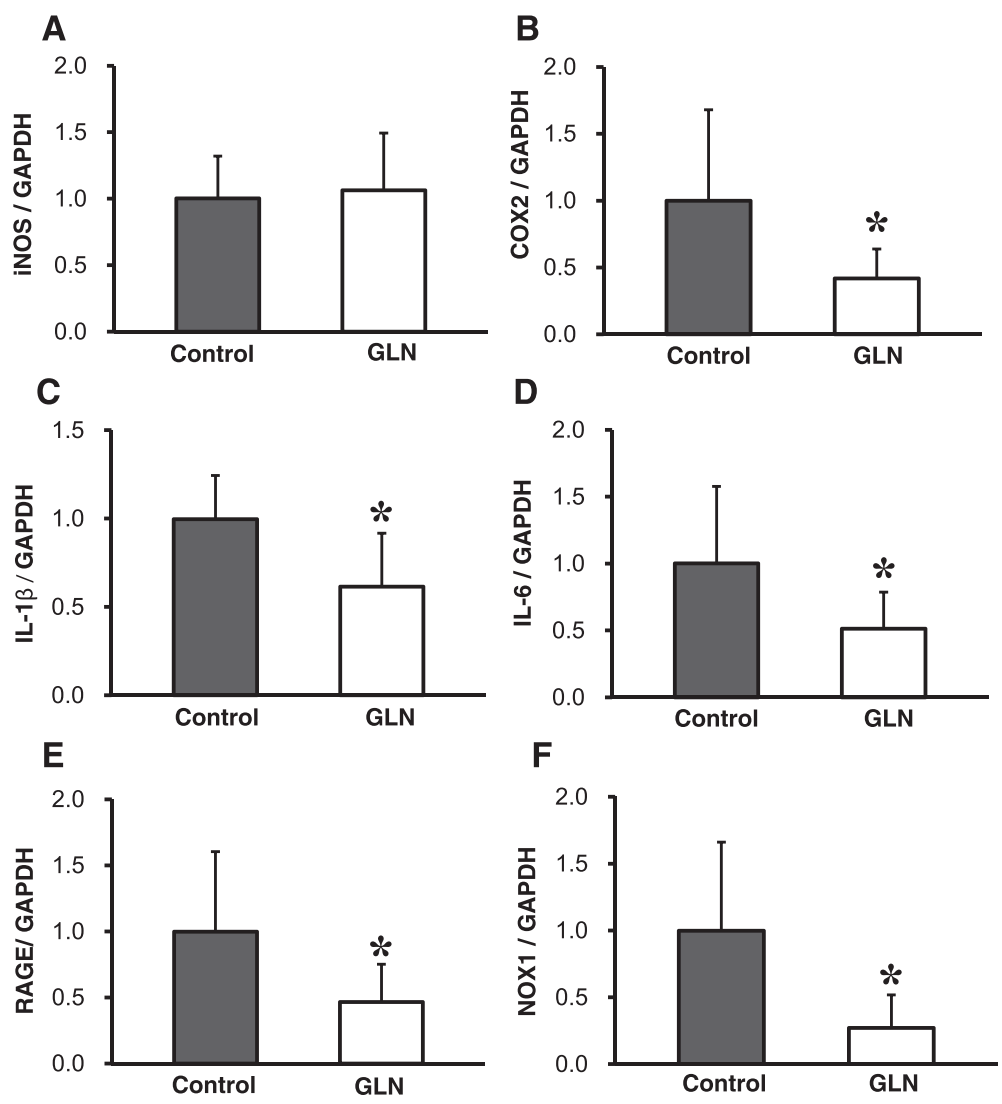

Figure 3 Relative mRNA levels of inflammatory genes in the lungs of ALI-challenged mice. (A) iNOS; (B) COX-2; (C) IL-1 $;$; (D) IL-6; (E) RAGE; (F) NOX-1. Each value was normalized to that of GAPDH, and the relative mRNA abundance was expressed as a fraction of that in the control group and assigned a value of 1 . Data are presented as mean \pm standard deviation; $n=10-12$. The effect of GLN was evaluated by Student's t-test in two ALl-induced groups ( ${ }^{*} p<0.05$ vs. the control group). 
in rats [34]. Lung injury and neutrophil infiltration were attenuated in NOX-1 null mice (deficient in the gp91 ${ }^{\text {phox }}$ and $47^{\text {phox }}$ subunits of Nox) [35,36]. NOX-1 inhibitors have been considered a potential therapy for ALI [34]. Therefore, NOX-1 inhibition might have an additional benefit in GLN-treated mice after ALI challenge.

MPO is a useful marker of neutrophil infiltration in different ALI models [37,38]. Our data showed that $3 \mathrm{~h}$ of ALI challenge resulted in significantly higher MPO activity than in unchallenged mice, but no abrogation effect was caused by GLN treatment. It is possible that the selected time point was not appropriate for GLN function, thus the decreased effect on MPO activity was not observed in our study, unlike previous reports $[39,40]$. On the other hand, toll-like receptor 4 (TLR4) signaling was believed to be another pathway of acid and LPS-induced ALI other than RAGE expression. In mice treated with adenovirusmediated siRNA targeting the TLR4 gene, a protective effect was shown against LPS challenge [41]. Thus, whether TLR4 signaling was involved in the beneficial effects of GLN remains to be explored in future studies.

\section{Conclusions}

Our results suggest that the beneficial effects of dietary GLN supplementation might be partially attributed to an inhibitory effect on RAGE expression and pro-inflammatory cytokine production at an early stage in acid- and LPS-induced ALI.

\section{Abbreviations \\ ALI: Acute lung injury; ARDS: Acute respiratory distress syndrome; BALF: Bronchoalveolar lavage fluid; CLP: Cecal ligation and puncture; COX-2: Cyclooxygenase-2; GLN: Glutamine; GAPDH: Glyceraldehyde-3- phosphate dehydrogenase; GSH: Glutathione; GPx: Glutathione peroxidase; GR: Glutathione reductase; GST: Glutathione S-transferase; HSP: Heat shock protein; HMGB-1: High-mobility group box protein-1; iNOS: Inducible nitric oxide synthase; IT: Intratracheally; LPS: Lipopolysaccharide; MMP: Metalloproteinase; MPO: Myeloperoxidase; NOX-1: NADPH oxidase-1; PMS: Post-mitochondrial fraction; PPAR: Peroxisome proliferator-activated receptor; RAGE: Receptor for advanced glycation end-products; SOD: Superoxide dismutase; TAS: Total antioxidant system; TLR-4: Toll-like receptor 4; TNF-a: Tumor necrosis factor-a.}

\section{Competing interest}

The authors declare that they have no conflict of interest.

\section{Authors' contributions}

Y-CC and C-CC provided the ALI model and technical guidance. H-MS conducted the analysis of antioxidative enzymes. H-JP and W-CL performed the experiments. H-LH designed and integrated this study, and drafted and revised the manuscript. All authors read and approved the final manuscript.

\section{Acknowledgments}

Our study was supported in part by research grant NSC98-2320-B-041-002-MY3 from the National Science Council, Taipei, Taiwan, Republic of China.

\section{Author details}

${ }^{1}$ Department of Medicine, Chi Mei Medical Center-Liou Ying, Tainan, Taiwan. ${ }^{2}$ Department of Health and Nutrition, Chia-Nan University of Pharmacy and Science, Tainan, Taiwan. ${ }^{3}$ Department of Medicine, Medical Research, Chi Mei Medical Center, Tainan, Taiwan.
Received: 21 March 2013 Accepted: 10 July 2014

Published: 15 July 2014

\section{References}

1. Raghavendran K, Nemzek J, Napolitano LM, Knight PR: Aspiration-induced lung injury. Crit Care Med 2011, 39:818-826.

2. Matthay MA, Zemans RL: The acute respiratory distress syndrome: pathogenesis and treatment. Annu Rev Pathol 2011, 6:147-163.

3. Chabot F, Mitchell JA, Gutteridge JM, Evans TW: Reactive oxygen species in acute lung injury. Eur Respir J 1998, 11:745-757.

4. Puneet $P$, Moochhala $S$, Bhatia M: Chemokines in acute respiratory distress syndrome. Am J Physiol Lung Cell Mol Physiol 2005, 288:L3-L15.

5. Guo WA, Knight PR, Raghavendran K: The receptor for advanced glycation end products and acute lung injury/acute respiratory distress syndrome. Intensive Care Med 2012, 38:1588-1598.

6. Su X, Looney MR, Gupta N, Matthay MA: Receptor for advanced glycation end-products (RAGE) is an indicator of direct lung injury in models of experimental lung injury. Am J Physiol Lung Cell Mol Physiol 2009, 297:L1-L5.

7. Zhang H, Tasaka S, Shiraishi Y, Fukunaga K, Yamada W, Seki H, Ogawa Y, Miyamoto K, Nakano Y, Hasegawa N, Miyasho T, Maruyama I, Ishizaka A: Role of soluble receptor for advanced glycation end products on endotoxin-induced lung injury. Am J Respir Crit Care Med 2008, 178:356-362.

8. Uchida T, Shirasawa M, Ware LB, Kojima K, Hata Y, Makita K, Mednick G, Matthay ZA, Matthay MA: Receptor for advanced glycation end-products is a marker of type I cell injury in acute lung injury. Am J Respir Crit Care Med 2006, 173:1008-1015.

9. Huttunen HJ, Fages C, Rauvala H: Receptor for advanced glycation end products (RAGE)-mediated neurite outgrowth and activation of NF-kappaB require the cytoplasmic domain of the receptor but different downstream signaling pathways. J Biol Chem 1999, 274:19919-19924.

10. Jian MY, Koizumi T, Kubo K: Effects of nitric oxide synthase inhibitor on acid aspiration-induced lung injury in rats. Pulm Pharmacol Ther 2005, 18:33-39.

11. Lima Trajano ET, Sternberg C, Caetano M, Santos Silva MA, Porto LC, Santos JC, Ribeiro ML, Magalhães CB, Zin WA, Benjamim CF, Valença SS: Endotoxin-induced acute lung injury is dependent upon oxidative response. Inhal Toxicol 2011, 23:918-926.

12. Weitzel LR, Wischmeyer PE: Glutamine in critical illness: the time has come, the time is now. Crit Care Clin 2010, 26:515-525. ix-x.

13. Wischmeyer PE: Glutamine in acute lung injury: the experimental model matters. Am J Physiol Lung Cell Mol Physiol 2009, 296:L286-L287.

14. Hu YM, Pai MH, Yeh CL, Hou YC, Yeh SL: Glutamine administration ameliorates sepsis-induced kidney injury by downregulating the high-mobility group box protein-1-mediated pathway in mice. Am J Physiol Renal Physiol 2012, 302:F150-F158.

15. Kwon WY, Suh GJ, Kim KS, Jo YH, Lee JH, Kim K, Jung SK: Glutamine attenuates acute lung injury by inhibition of high mobility group box protein-1 expression during sepsis. Brit J Nutr 2010, 103:890-898.

16. Reeves PG, Nielsen FH, Fahey GC Jr: AIN-93 purified diets for laboratory rodents: final report of the American Institute of Nutrition ad hoc writing committee on the reformulation of the AIN-76A rodent diet. J Nutr 1993, 123:1939-1951.

17. Lai YN, Yeh SL, Lin MT, Shang HF, Yeh CL, Chen WJ: Glutamine supplementation enhances mucosal immunity in rats with gut-derived sepsis. Nutrition 2004, 20:286-291.

18. Yeh SL, Lai YN, Shang HF, Lin MT, Chen WJ: Effects of glutamine supplementation on innate immune response in rats with gut-derived sepsis. Br J Nutr 2004, 91:423-429.

19. Chiang SR, Chuang YC, Tang HJ, Chen CC, Chen CH, Lee NY, Chou CH, Ko WC: Intratracheal colistin sulfate for BALB/C mice with early pneumonia caused by carbapenem-resistant Acinetobacter baumannii. Crit Care Med 2009, 37:2590-2595.

20. Akcan A, Muhtaroglu S, Akgun H, Akyildiz H, Kucuk C, Sozuer E, Yurci A, Yilmaz N: Ameliorative effects of bombesin and neurotensin on trinitrobenzene sulphonic acid-induced colitis, oxidative damage and apoptosis in rats. World J Gastroenterol 2008, 14:1222-1230.

21. Osburn WO, Karim B, Dolan PM, Liu G, Yamamoto M, Huso DL, Kensler TW: Increased colonic inflammatory injury and formation of aberrant crypt foci in Nrf2-deficient mice upon dextran sulfate treatment. Int J Cancer 2007, 121:1883-1891.

22. Lowry OH, Rosebrough NJ, Farr AL, Randall RJ: Protein measurement with the Folin phenol reagent. J Biol Chem 1951, 193:265-275. 
23. Huang CJ, Shaw HM: Tissue vitamin E status is compromised by dietary protein insufficiency in young growing rats. J Nutr 1994, 124:571-579.

24. Shaw HM, Zhang $L Y$, Huang HL: The effects of sucrose water and food restriction on antioxidative status in rats. Chia Nan Ann Bull 2009, 35:172-180.

25. Singleton KD, Wischmeyer PE: Glutamine attenuates inflammation and NF-kappaB activation via Cullin-1 deneddylation. Biochem Biophys Res Commun 2008, 373:445-449.

26. Zhou GJ, Zhang H, Zhi SD, Jiang GP, Wang J, Zhang M, Gan JX, Xu SW, Jiang GY: Protective effect of raloxifene on lipopolysaccharide and acid-induced acute lung injury in rats. Acta Pharmacol Sin 2007, 28:1585-1590.

27. Abraham E, Arcaroli J, Carmody A, Wang H, Tracey KJ: HMG-1 as a mediator of acute lung inflammation. J Immunol 2000, 165:2950-2954.

28. Yamakawa N, Uchida T, Matthay MA, Makita K: Proteolytic release of the receptor for advanced glycation end products from in vitro and in situ alveolar epithelial cells. Am J Physiol Lung Cell Mol Physiol 2011, 300:L516-L525.

29. Damas $P$, Ledoux D, Nys M, Vrindts Y, De Groote D, Franchimont P, Lamy M: Cytokine serum level during severe sepsis in human IL- 6 as a marker of severity. Ann Surg 1992, 215:356-362.

30. Yeh CL, Hsu CS, Yeh SL, Chen WJ: Dietary glutamine supplementation modulates Th1/Th2 cytokine and interleukin-6 expressions in septic mice. Cytokine 2005, 31:329-334.

31. Singleton KD, Wischmeyer PE: Glutamine's protection against sepsis and lung injury is dependent on heat shock protein 70 expression. Am J Physiol Regul Integr Comp Physiol 2007, 292:R1839-R1845.

32. Fukunaga K, Kohli P, Bonnans C, Fredenburgh LE, Levy BD: Cyclooxygenase 2 plays a pivotal role in the resolution of acute lung injury. J Immunol 2005, 174:5033-5039.

33. Badwey JA, Karnovsky ML: Active oxygen species and the functions of phagocytic leukocytes. Annu Rev Biochem 1980, 49:695-726.

34. Carnesecchi S, Pache JC, Barazzone-Argiroffo C: NOX enzymes: potential target for the treatment of acute lung injury. Cell Mol Life Sci 2012, 69:2373-2385.

35. Farley KS, Wang L, Mehta S: Septic pulmonary microvascular endothelial cell injury: role of alveolar macrophage NADPH oxidase. Am J Physiol Lung Cell Mol Physiol 2009, 296:L480-L488.

36. Sato K, Kadiiska MB, Ghio AJ, Corbett J, Fann YC, Holland SM, Thurman RG, Mason RP: In vivo lipid-derived free radical formation by NADPH oxidase in acute lung injury induced by lipopolysaccharide: a model for ARDS. FASEB J 2002, 16:1713-1720.

37. Winterbourn CC, Kettle AJ: Reactions of superoxide with myeloperoxidase and its products. Jpn J Infect Dis 2004, 57:S31-S33.

38. Wu F, Liu Y, Lv X, Miao X, Sun Y, Yu W: Small interference RNA targeting TLR4 gene effectively attenuates pulmonary inflammation in a rat model. J Biomed Biotechnol 2012, 2012:406435.

39. Wischmeyer PE, Kahana M, Wolfson R, Ren H, Musch MM, Chang EB: Glutamine reduces cytokine release, organ damage, and mortality in a rat model of endotoxemia. Shock 2001, 16:398-402.

40. Yeh CL, Hsu CS, Yeh SL, Lin MT, Chen WJ: Dietary glutamine supplementation reduces cellular adhesion molecule expression and tissue myeloperoxidase activity in mice with gut-derived sepsis. Nutrition 2006, 22:408-413.

41. Imai Y, Kuba K, Neely GG, Yaghubian-Malhami R, Perkmann T, van Loo G, Ermolaeva M, Veldhuizen R, Leung YH, Wang H, Liu H, Sun Y, Pasparakis M, Kopf M, Mech C, Bavari S, Peiris JS, Slutsky AS, Akira S, Hultqvist M, Holmdahl R, Nicholls $J$, Jiang $C$, Binder $C$, Penninger JM: Identification of oxidative stress and Toll-like receptor 4 signaling as a key pathway of acute lung injury. Cell 2008 133:235-249

doi:10.1186/1471-2466-14-115

Cite this article as: Chuang et al:: Short-term glutamine supplementation decreases lung inflammation and the receptor for advanced glycation end-products expression in direct acute lung injury in mice. BMC Pulmonary Medicine 2014 14:115

\section{Submit your next manuscript to BioMed Central and take full advantage of:}

- Convenient online submission

- Thorough peer review

- No space constraints or color figure charges

- Immediate publication on acceptance

- Inclusion in PubMed, CAS, Scopus and Google Scholar

- Research which is freely available for redistribution

Submit your manuscript at www.biomedcentral.com/submit
Ciomed Central 